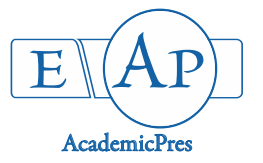

Ojo SS et al. (2021)

Notulae Scientia Biologicae 13(1):10873

DOI: $10.15835 / \mathrm{nsb} 13110873$

Research Article

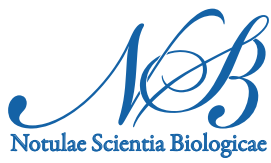

\title{
Microbial assessment and proximate composition of bread samples collected from different bakeries in Ogbomoso, Oyo state, Nigeria
}

\author{
Segun S. OJO ${ }^{1}$, Adekunle O. ADEOYE ${ }^{1 *}$, Adeladun S. AJALA ${ }^{1}$, \\ Iyabo C. OLADIPO ${ }^{2}$
}

\begin{abstract}
${ }^{1}$ Ladoke Akintola University of Technology, Department of Food Science and Engineering, Ogbomoso, Oyo State, Nigeria; sojo@lautech.edu.ng; aoadeoye@lautech.edu.ng ('correspondingauthor); asajala@lautech.edu.ng

${ }^{2}$ Ladoke Akintola University of Technology, Department of Science, Laboratory of Technology, Ogbomoso, Oyo State, Nigeria; icoladipo@lautech.edu.ng
\end{abstract}

\begin{abstract}
Bread is a staple food in Nigeria and establishment of bakeries depend on the financial capacity and processing technique employed by processors. This has led to various breads in terms of nutrition and asepsis. In this study, three types of ready-to-eat bread were purchased from different bakery retail shops in Ogbomoso, Nigeria. The control sample was prepared in Food Science Department, Ladoke Akintola University of Technology Ogbomoso. These samples were analyzed for proximate composition, bacterial and fungal contamination using standard microbial procedure (SMP) and disc diffusion method (DDM) for sensitivity test to investigate safety handling practices during production, distribution and anti-microbial effect on microbial contaminant. The results of microbial analysis are as follows: total viable count $\left(1.1 \times 10^{3}-4.5 \times 10^{3}\right)$ $\mathrm{cfu} / \mathrm{g}$, coliform count $\left(0-1.9 \times 10^{3}\right) \mathrm{cfu} / \mathrm{g}$, and mold count $\left(0.3 \times 10^{5}-3.7 \times 10^{5}\right) \mathrm{cfu} / \mathrm{g}$. The percentage of organisms isolated were E. coli. $15 \%$, B. subtilis and S. aureus $20 \%$, P. aureginosa $10 \%$, S. cerevisiae $15.77 \%$, R. stolonifer $13.46 \%$, Mucor spp. and $A$. niger $18.08 \%$, and $P$. notatum $7.69 \%$. The result of the proximate analysis was as follows: protein (9.13-9.79\%), crude fat (1.64-4.50\%), ash (1.32-1.77\%), crude fibre (0.10-0.23\%), moisture content $(27.22-29.05 \%)$ and carbohydrate $(55.89-59.40 \%)$. The most sensitive antimicrobial agent was gentamycin across treatment. The organisms restricted septrin, augmenting, and chloramphenicol completely. Bacillus subtilis has the highest zone of inhibition with the use of gentamycin.
\end{abstract}

Keywords: antimicrobial; bread; contamination; inhibition and safety

\section{Introduction}

Bread is a common food product, produce by baking dough obtain from a mixture of recipe of flour, water, sugar, salt, yeast (Adebayo-Oyetoro et al., 2016). Bread is processed as either rich bread (sweet roll) which has sugar, eggs and milk / flavoring added to flour and rising agent while yeast bread is processed from flour, fat, liquid, yeast milk and salt. Yeast bread is the most popular in Nigeria (WHO, 2002). However, the storage, handling process, the environment for processing and health of the workers in the cottage industries and

Received: 29 Dec 2020. Received in revised form: 01 Mar 2021. Accepted: 03 Mar 2021. Published online: 09 Mar 2021.

From Volume 13, Issue 1, 2021, Notulae Scientia Biologicae journal will use article numbers in place of the traditional method of continuous pagination through the volume. 
hawkers in the street are matter of concern for the safety of the consumers. Food borne diseases are reported to be widespread in the contemporary world and responsible for about one third of death worldwide (WHO, 2007). Also, widespread occurrence of staphylococcus as food poisoning had been said to result from close association of animal to humans within food preparation area (WHO, 2002). Some bacteria that are harmful from public health point of view may multiply to dangerously high levels in the food without changing the appearance, odor and taste of the food (Musaiger, 2007; Sausa, 2008). More so, the most common food handling mistakes are cited to include serving contaminated raw food materials, inadequate cooking or reheating of cooked foods obtained from unsaved sources, cooking food inappropriately and allowing too much of time lapse between cooking and consumption (Bryan et al., 1988; Lateef et al., 2010a).

A diverse group of pathogens and infections are encountered from food and food product antibiotics deserved their place as one of the pillars of modern medical care. The introduction of every antimicrobial agent into clinical practice has been followed by the detection in the laboratory of strains of micro-organisms that are resistant (able to multiply in the presence of drug concentrations (WHO, 2002; Achi and Madubuike, 2007).

Today, bakery products make a major component of our daily diet. People used to prepare and consume fresh food at home. Now the trends are changing as the people are trying to keep up with the hectic routines of busy life. The convenience food sectors are evolving accordingly to keep up with the need of the time and many ready-to-eat and semi ready-to-eat products are offered at bakery and the fast-food outlets. Among these ready to-eat food products, the bakery products offer convenience and balanced diet at the same time for the busy and health conscious customers (Musaiger, 2007; Afolabi, 2015). However, Abdalla (2009) reported that major food borne pathogen or disease are reported to be in many ready to eat foods which include bread and bread-like products especially in Asia and Africa. Therefore, this study aims to verify the safety of breads consumed in Ogbomoso.

Significant of study

The significance of this study is safety assessment of the bread from the production, distribution to consumption. Therefore, the study shows possible anti-microbial treatment that may be used to combat outbreak of food contamination due to infection traceable to these ready-to-eat-food.

\section{Materials and Methods}

\section{Samples collection}

Materials used for this research work were three types of bread purchased from three randomly selected bakeries in Ogbomoso. These bakeries were designated as B, C, D. Control sample was the bread processed and baked in Food Science Laboratory LAUTECH Ogbomoso, Oyo State, Nigeria and designated as sample A. Each bread samples from each hawker was placed in airtight container. They were then taken to microbiology laboratory for analysis.

\section{Proximate analysis of bread samples}

Ash content, crude protein, fat content, crude fiber, moisture content and carbohydrate were determined using the official methods of (AOAC, 2005).

\section{Microbial analysis of bread samples}

One gram of each bread sample was weighed out and blended aseptically in the sterile mortar. $9 \mathrm{mls}$ of distilled water was added. Ten- fold serial dilution was carried out. The dilution was serially made up to 1 : $10,000\left(10^{4}\right)$. With the aid of wax pencil, the bottom of the petri dishes was properly labeled with the sample code, dilution factor, media used and date. With the use of sterile pipette $1 \mathrm{ml}$ of the aliquots prepared from each of the bread was aseptically transferred from dilution 1: $1000\left(10^{3}\right)$ into Petri dishes in triplicates. Sterilely 
prepared plate count agar (PCA) and potato dextrose agar (PDA) were used for the pour plate method. About $25 \mathrm{mls}$ PCA were poured into each of the plate labeled for total bacterial count, while about $25 \mathrm{mls}$ PDA were poured into each of the plate labeled total fungi count. These media were aseptically poured at about $45^{\circ} \mathrm{C}$ to avoid killing the organisms present in the samples. The plates of PCA were incubated for 24 hours while the plates of PDA were incubated at room temperature for 6 days.

After incubation, the morphological features and pigmentation of the emerged colonies were examined, it was Subculture to obtain pure colonies. Preliminary identification was done based on colonial morphology and pigmentation studied. Gram's staining was done as described by Fawole and Oso (2004). Biochemical test applied were nitrate, voges proskauer, citrate utilization, oxidase, coagulase and spore test while sugar fermentation done include lactose, sucrose, maltose, manitol and fructose. Characterization and identification were done using the method of (Fawole and Oso, 2004).

\section{Culture media used}

The media used for the microbiological isolation of microorganism were nutrient agar and potato dextrose agar. Nutrient agar was used for the isolation of bacteria and potato dextrose agar used for the isolation of fungi. The media were prepared according to the manufacturer's instruction.

\section{Isolation of microorganisms}

One gram of each bread samples was taken at intervals of $2 \mathrm{~h}$, starting from $0-8 \mathrm{~h}$ and placed in a bottle containing $9 \mathrm{ml}$ of distilled water and shaker to allow homogenization of the solution, the resulting solution was then serially diluted. One was drawn from the eight-fold dilution, which was then introduced into the already prepared solidified agar inside sterile petri-dishes. The agar used, nutrient agar and potato dextrose agar, was incubated for $24 \mathrm{~h}$ at $37^{\circ} \mathrm{C}$ respectively.

For the isolation of fungi, potatoes dextrose agar plates were seeded with $0.1 \mathrm{ml}$ aliquot from $10^{-2}$ dilution of crushed bread sample using the spread plate technique. A sterile spreader was used to spread the inoculums on the plates and the plates were incubated at room temperature for 48 hours. The plates were examined for fungal growth after every $24 \mathrm{~h}$.

\section{Culture examination}

The incubated isolates were checked after $24 \mathrm{~h}$ for visible colonies and the visible colonies were counted on both plates containing Nutrient Agar and potato dextrose agar. Fresh medium was prepared and sterilized at $121{ }^{\circ} \mathrm{C}$ for $15 \mathrm{~m}$ and allow to cool, it was then poured aseptically into sterile Petri-dishes. The isolates on the serial diluted plate was subculture onto new plates by streaking method in order to get a pure colony. The plates were incubated at $37^{\circ} \mathrm{C}$ for $24 \mathrm{~h}$ for proper growth of the isolates and then observe for pure colony after $24 \mathrm{~h}$ of incubation.

\section{Culture preservation}

Distinct pure colony was picked by the use of sterile needle and was inoculated into a prepared sterile agar slant of nutrient agar and potato dextrose agar. This was incubated at $37^{\circ} \mathrm{C}$ for $24 \mathrm{~h}$, and the slant with visible growth on the surface of the agar is then preserved in the refrigerator at $4{ }^{\circ} \mathrm{C}$.

\section{Characterization of the bacteria isolates}

Colonial characteristics of the bacteria isolates were determined using parameters such as size, elevation, pigment, surface, opacity, edge and shape. Cellular and biochemical characteristics of the isolates were determined as follows: gram staining, motility test, spore staining, capsule staining, catalase test, oxidase test, starch hydrolysis, citrate utilization, oxygen relationship, sugar fermentation. 


\section{Characterization of fungal isolates}

The fungal isolates were characterized using their colonial morphology on the plates. Parameters such as color of the colonies, nature of the hyphae, appearance of the colonies and the growth rates were considered for proper characterization of the isolates.

Microscopic examinations of the isolates were also carried out. Reproductive and vegetative structures were observed. Nature of spores, nature of sporangia, branching of the hyphae and presence of septa were all considered during microscopy. Microscopic examination of the fungal isolates was carried out as described below.

A drop of cotton blue in lactophenol stain was placed on a clean slide. A mounted needle was used to remove a small portion of mycelium from the colony of each fungal isolate and placed in the drop of stain. The specimen was spread very well with the aid of two mounted needles. A cover slip was gently lowered on the slide. Excess stain was wiped off by putting the slide between two pieces of filter papers. The filter paper was pressed gently against the slide.

The slide was then examined under the microscope. The procedure was repeated for all the fungal isolates (Fawole and Oso, 2004). Fungal identification was carried out according to the procedure described by (Samson, 1981).

\section{Antibiotic susceptibility test}

The commercially purchased antibiotics discs were used to determine the susceptibility of organisms to therapy with antibiotics; this test was carried out on each isolate from the different bread samples in order to determine their susceptibility to antibiotics. The disc diffusion method was used because of convenience, efficiency and cost. The inocula for the test were prepared using $18 \mathrm{~h}$ old culture of the isolates $(1 \mathrm{~g}-9 \mathrm{ml})$. These were spread evenly onto the surface of the already prepared diagnostic agar sterile petri dishes by using inoculating loop and spreader. The antibiotics disc was placed at the center of the plate and was pressed to ensure firm contact. It was thereafter incubated at $37^{\circ} \mathrm{C}$ for $24 \mathrm{~h}$. The ability of antibiotics to inhibit the growth of the organism was indicated by the appearance of clear zone around the edge of the antibiotic disc (sensitivity), otherwise is resistance (Isong, 2013). Acceptability range of the standard was determined by International Commission on Microbiological Specification for Food (ICMSF, 1998).

\section{Results and Discussion}

\section{Proximate composition}

The proximate composition of bread purchased from three different bakeries and the control sample processed in Food Science Laboratory, LAUTECH, Ogbomoso, is shown in Table 1. The protein content ranged between $9.23 \pm 0.09^{\mathrm{a}}$ and $9.79 \pm 0.11^{\mathrm{d}}$. Sample A (Control) had the highest protein content while sample D had the least protein content among all. This may be due to the brand of flour used in making the bread. Protein is an efficient nutrient which serves as strength and body builder. Sample B and D were not significantly different while sample $A$ and $C$ differs significantly at $\mathrm{P} \leq 0.05$. The percentage of fat in sample $\mathrm{B}$ is higher while sample $\mathrm{D}$ is lower. The decrease in fat content of bread produced from sample $\mathrm{D}$ might be due to reduction in fat applied during preparation.

The fat content ranged between $1.64 \pm 0.04^{\mathrm{a}}$ and $4.50 \pm 0.12^{\mathrm{c}}$ Sample A and D were not significantly different while sample $B$ and $C$ differs significantly at $P \leq 0.05$. The crude fibre ranged between $0.10 \pm 0.02^{a}$ and $0.23 \pm 0.01^{\mathrm{d}}$. The crude fibre content of bread produced in sample B (LAUTECH bread) had the highest crude fibre while sample $C$ had the least among the samples. Fibre is known to help in lowering of serum cholesterol. All samples A, B, C and D differs significantly at $\mathrm{P} \leq 0.05$. The ash content of bread samples ranged between $1.32 \pm 0.03^{\mathrm{a}}$ and $1.77 \pm 0.02^{\mathrm{c}}$ as the bread produced in sample $\mathrm{D}$ had the highest ash content more than the bread

produced from the other bakeries. This implies that the mineral content of the wheat flour used in making 
sample $\mathrm{D}$ is higher than those used in other local bakeries. Also, the other ingredients in the recipe for example, salt, differ from one bakery to another and may also contribute to the mineral level. Sample A and C were not significantly different while sample $\mathrm{B}$ and $\mathrm{D}$ differs significantly at $\mathrm{P} \leq 0.05$.

The moisture content ranged between $17.22 \pm 0.38^{\mathrm{a}}$ and $19.05 \pm 0.21^{\mathrm{b}}$. Moisture content of the bread produced in sample D had the highest moisture content while sample A (control) had the least moisture content. This implies that bread with highest moisture content can easily get spoilt or deteriorate. Sample B, C and $\mathrm{D}$ were not significantly different while sample A differs significantly at $\mathrm{P} \leq 0.05$. Carbohydrate content ranged between $55.89 \pm 0.50^{\mathrm{a}}$ and $59.40 \pm 0.27^{\mathrm{d}}$. Sample A (control bread) had the highest carbohydrate content while sample B (LAUTECH bread) had the least carbohydrate content among all the samples. This shows that wheat flour is of higher carbohydrate percentage but varied in percentage used for bread in each bakery. All samples A, B, C and D differs significantly at $\mathrm{P} \leq 0.05$.

Table1. Proximate composition of bread samples

\begin{tabular}{|c|c|c|c|c|c|c|}
\hline Sample & Mc (\%) & Protein (\%) & Ash (\%) & Fat (\%) & Fibre (\%) & Cho (\%) \\
\hline A & $27.22 \pm 0.38^{\mathrm{a}}$ & $9.79 \pm 0.11^{\mathrm{d}}$ & $1.38 \pm 0.04^{\mathrm{a}}$ & $1.76 \pm 0.04^{\mathrm{a}}$ & $0.15 \pm 0.03^{\mathrm{b}}$ & $59.40 \pm 0.27^{\mathrm{d}}$ \\
\hline B & $28.45 \pm 0.36^{\mathrm{b}}$ & $9.29 \pm 0.06^{\mathrm{a}}$ & $1.60 \pm 0.09^{\mathrm{b}}$ & $4.50 \pm 0.12^{\mathrm{c}}$ & $0.23 \pm 0.01^{\mathrm{d}}$ & $55.89 \pm 0.50^{\mathrm{a}}$ \\
\hline C & $28.99 \pm 0.26^{\mathrm{b}}$ & $9.57 \pm 0.06^{\mathrm{c}}$ & $1.32 \pm 0.03^{\mathrm{a}}$ & $2.40 \pm 0.06^{\mathrm{b}}$ & $0.10 \pm 0.02^{\mathrm{a}}$ & $58.63 \pm 0.32^{\mathrm{c}}$ \\
\hline D & $29.05 \pm 0.21^{\mathrm{b}}$ & $9.23 \pm 0.09^{\mathrm{a}}$ & $1.77 \pm 0.02^{\mathrm{c}}$ & $1.64 \pm 0.04^{\mathrm{a}}$ & $0.20 \pm 0.01^{\mathrm{c}}$ & $57.21 \pm 0.02^{\mathrm{b}}$ \\
\hline
\end{tabular}

Key: Duncan multiple arrangement test (DURT) ANOVA P< 0.05, A: control sample, B: LAUTECH bread, C: Onile-ayo bread, D: Success bread.

\section{Microbial analysis results}

The microbial count as shown in Table 2 revealed the total viable count ranged between $1.1 \times 10^{3} \pm 0.30^{\mathrm{a}}$ and $4.5 \times 10^{3} \pm 0.20^{\mathrm{d}}$. Sample A (control) had the lowest viable count while sample B (LAUTECH bread) had highest viable count. The total coliform count ranged between $0.0 \times 10^{3} \pm 0.00^{\mathrm{a}}$ and $1.9 \times 10^{3} \pm 0.10^{\mathrm{d}}$. Sample $\mathrm{A}$ (control) was zero while sample B (LAUTECH bread) had the highest coliform count. According to coliform count, compared to the Codex Alimentarius commission of the United Nations, the results of this analysis indicate the class $B$ food grade category due to high level of coliform organisms in the food samples, this indicate low level of hygiene practices (FEHD, 2002). The mold count ranged between $0.3 \times 10^{5} \pm 0.10^{\mathrm{a}}-3.7 \times 10^{5} \pm$ $0.10^{\mathrm{d}}$. Sample A (control) had the lowest count while sample B had the highest mold count. These were in confirmation with the report of (Abdalla et al., 2009), that the general stage of inadequate hygiene and sanitation could count for organisms in food.

Table 2. Microbial count of bread samples

\begin{tabular}{|c|c|c|c|}
\hline Sample & TVC $(\mathrm{cfu} / \mathrm{ml})$ & Coliform $(\mathrm{cfu} / \mathrm{ml})$ & Mold count $(\mathrm{sfu} / \mathrm{ml})$ \\
\hline A & $1.1 \times 10^{3} \pm 0.30^{\mathrm{a}}$ & $0.0 \times 10^{3} \pm 0.00^{\mathrm{a}}$ & $0.3 \times 10^{5} \pm 0.10^{\mathrm{a}}$ \\
\hline B & $4.5 \times 10^{3} \pm 0.20^{\mathrm{d}}$ & $1.9 \times 10^{3} \pm 0.10^{\mathrm{d}}$ & $3.7 \times 10^{5} \pm 0.10^{\mathrm{d}}$ \\
\hline C & $3.6 \times 10^{3} \pm 0.10^{\mathrm{b}}$ & $1.5 \times 10^{3} \pm 0.30^{\mathrm{c}}$ & $2.9 \times 10^{5} \pm 0.10^{\mathrm{c}}$ \\
\hline D & $1.7 \times 10^{3} \pm 0.20^{\mathrm{b}}$ & $0.9 \times 10^{3} \pm 0.20^{\mathrm{b}}$ & $0.7 \times 10^{5} \pm 0.20^{\mathrm{b}}$ \\
\hline
\end{tabular}

These bacteria count of sample B, C and D were less than $10^{5} \mathrm{cfu} / \mathrm{g}$ recommended limits for bacterial contamination for ready-to-eat food by international commission on microbiological specification for foods. Also, the results in this study are comparable to report from many previous works (Isong, 2013) that the presence of large microbial population in some foods is due to unhygienic practices by food handlers. All samples A, B, C and D differs significantly at $\mathrm{P} \leq 0.05$. According to (Feltes et al., 2017), many organisms have been found to proliferate in food readily at a wide range of temperatures. The total fungal count of the four samples of bread as shown in Table 2 is within the acceptable range of the standard by the International Commission on Microbiological specification for food (ICMSF, 1998). 
Table 3. Distribution of bacteria contaminant in the bread samples

\begin{tabular}{|c|c|c|c|c|}
\hline Microorganisms & A & B & C & D \\
\hline E. coli & - & + & + & + \\
\hline Bacillus subtilis & + & + & + & + \\
\hline Staphylococcus aureus & + & + & + & + \\
\hline Pseudomonas aeruginosa & - & + & + & - \\
\hline
\end{tabular}

Key: -Nill, +: Positive

The microscopic and biochemical tests to characterize the isolated micro-organism as recorded in Table 4 revealed the isolated fungi were $S$. cerevisiae, $R$. stolonifer, Mucor sp., and $A$. niger. This may be due to inadequate hygiene and sanitation during processing (FEHD, 2002).

The distribution of bacteria contaminant as shown in Table 4 have different variation while Table 5 shows the distribution of fungi contaminant which also varies as well.

Table 4. Distribution of fungi contaminant in the bread sample

\begin{tabular}{|c|c|c|c|c|}
\hline Microorganisms & $\mathrm{A}$ & $\mathrm{B}$ & $\mathrm{C}$ & $\mathrm{D}$ \\
\hline Saccharomyces cerevisiae & + & + & + & + \\
\hline Rhizopus stolonifer & - & + & - & + \\
\hline Mucor spp. & + & + & - & + \\
\hline Aspergillus niger & - & + & + & + \\
\hline Penicillium notatum & - & - & - & + \\
\hline
\end{tabular}

Table 5. Bacterial sensitivity test of isolates from bread samples

\begin{tabular}{|c|c|c|c|c|}
\hline \multirow{2}{*}{ Antibiotics } & \multicolumn{4}{|c|}{ Zone of inhibition in mm } \\
\cline { 2 - 5 } & \multirow{2}{*}{ E. coli } & $\begin{array}{c}\text { Bacillus } \\
\text { subtilis }\end{array}$ & Staphylococcus aureus & $\begin{array}{c}\text { Pseudomonas } \\
\text { aeruginosa }\end{array}$ \\
\hline Chloramphenicol & 9 & 7 & 12 & 8 \\
\hline Amoxicillin & 5 & 13 & 14 & 15 \\
\hline Augmentin & 11 & 6 & 10 & 12 \\
\hline Gentamycin & 19 & 30 & 22 & 16 \\
\hline Streptomycin & 11 & 22 & 18 & 21 \\
\hline Ampicillin & 8 & 10 & 15 & 10 \\
\hline Erythromycin & 6 & 9 & 12 & - \\
\hline Septrin & 12 & 7 & 8 & - \\
\hline Pefloxacin & - & - & - & \\
\hline
\end{tabular}

The bacterial isolates as shown in Table 6 varies in their percentage sensitivity and are mostly sensitive to gentamycin, streptomycin, ampicillin erythromycin and amoxicillin, while the fungal isolates as recorded in Table 7 showed that they are mostly sensitive to nistatin. The organisms resisted griseofulvin, mic oten, augmentin, septrin, and chloramphenicol completely. This may be as a result of drug abuse or misuse (Isong, 2013). Table 8 shows the frequency occurrence of bacteria isolates while Figure 1 shows the frequency occurrence of fungi isolates in the samples. Figure 1 shows the antibiotic susceptibility profile of bacteria isolates from bread while Figure 2 shows the Antibiotic Susceptibility profile of fungi from bread samples. 
Ojo SS et al. (2021). Not Sci Biol 13(1):10873

Table 6. Fungal sensitivity test of isolates from bread samples

\begin{tabular}{|c|c|c|c|c|c|}
\hline \multirow{2}{*}{ Antifungicide } & \multicolumn{5}{|c|}{ Zone of inhibition in mm } \\
\cline { 2 - 6 } & Saccharomyces cerci & $\begin{array}{c}\text { Penicillium } \\
\text { notatum }\end{array}$ & $\begin{array}{c}\text { Rhizospus } \\
\text { stolonipher }\end{array}$ & Mucor spp. & Aspergillus niger \\
\hline Nystatin & 29 & 18 & 12 & 28 & 32 \\
\hline Griseofulvin & 12 & 13 & 17 & 21 & 24 \\
\hline Ketxonazole & - & - & - & - & - \\
\hline Mycoten & 6 & 7 & 12 & 11 & 23 \\
\hline
\end{tabular}

Table 7. Frequency occurrence of bacteria isolated from bread samples

\begin{tabular}{|c|c|c|}
\hline Bacterial isolated & Frequency of occurrence n-20 & Percentage (\%) \\
\hline E. coli & 3 & 15 \\
\hline B. subtilis & 4 & 20 \\
\hline S. aureus & 4 & 20 \\
\hline P. aeruginosa & 2 & 10 \\
\hline
\end{tabular}

Table 8. Frequency occurrence of fungi isolated from bread samples

\begin{tabular}{|c|c|c|}
\hline Fungi isolated & Frequency of occurrence & Percentage (\%) \\
\hline S. cerevisiae & 4 & 30.77 \\
\hline R. stolonifer & 2 & 15.38 \\
\hline Mucor spp. & 3 & 23.08 \\
\hline A. niger & 3 & 23.08 \\
\hline P. notatum & 1 & 7.69 \\
\hline Total & 13 & 100 \\
\hline
\end{tabular}

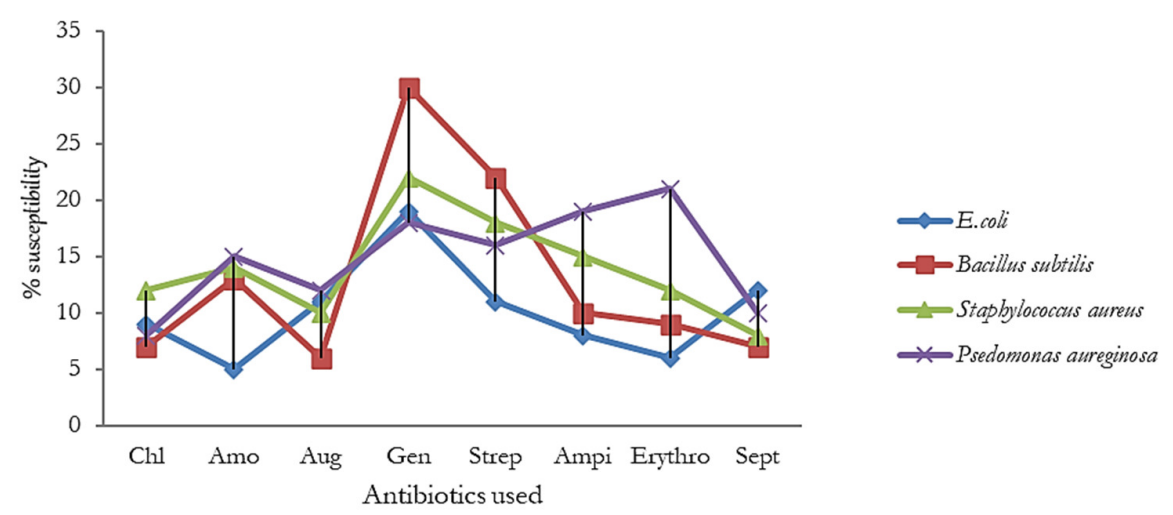

Figure 1. Antibiotic susceptibility profile of bacterial isolated from bread Chl - Chloramphenicol, Amo - Amoxicillin, Aug - Augumentin,Gen - Gentamycin, Strp- Streptomycin, Ampi Ampicillin, Erythro - Erythromycin Sept-Septrin 


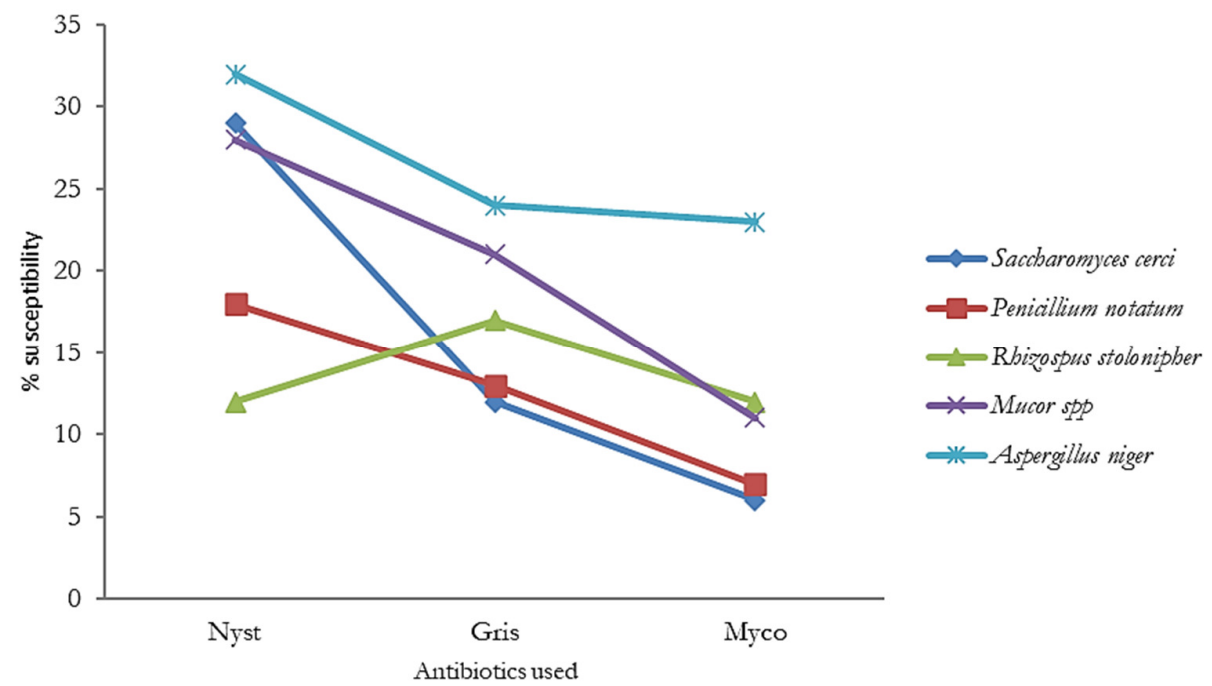

Figure 2. Antibiotic Susceptibility profile of fungi isolated from bread Nyst - Nystatin, Gris - Griseofulvin, Myco - Mycoten.

\section{Conclusions}

It can be concluded from the result of the proximate analysis that the differences in the parameters analysed was as a result of the components of wheat flour and recipe formulation, since additives and ingredients composition added as formulation of each bakery is different from each other. The microbial isolates found were attributed to level of hygienic practices, handling and health of workers. The products were temperatures and high range of moisture content which favored multiplication of microbes after contamination. Antimicrobial sensitivity test carried out shows that gentamycin was most effective across the treatment and Bacillus subtilis has the highest zone of inhibition. The combined study of proximate and microbial load as reflected in the analysis allows studying of influence of proximate parameters such as \% moisture, protein and fat content on microbial load of the samples. The need to provide more information on safety in distribution chains of bread to ensure good handling practices has been examined and the study recommends training of handlers who engage in handling of bread during distributions.

\section{Authors' Contributions}

OSS - Methodology, analysis, data collation, investigation, funding; AAO - Writing-original draft, investigation, review and editing, funding; AAS - Software, validation supervision, funding; OIC - Project administration

All authors read and approved the final manuscript.

\section{Acknowledgements}

The facilities used for this study were provided by Ladoke Akintola University of Technology, Oyo State, Nigeria 


\section{Conflict of Interests}

The authors declare that there are no conflicts of interest related to this article.

\section{References}

Abdalla MA, Suliman SE, Bakhiet AO (2009). Food safety knowledge and practices of street food-vendors in Atbara City (Naher Elneel State Sudan). African Journal of Biotechnology 8(24):6967-6971.

Adebayo-Oyetoro AO, Ogundipe OO, Adeeko KN (2016). Quality assessment and consumer acceptability of bread from wheat and fermented banana flour. Food Science and Nutrition 4(3):364- 369. https://doi.org/10.1002/fsn3.298

Achi OK, Madubuike CN (2007). Prevalence and antimicrobial resistance of Staphylococcus aureus isolated from retail ready-to eat foods in Nigeria. Journal of Microbiology 2:373-383. https://doi.org/10.3923/jm.2007.516.523

Afolabi OT, Aluko OO, Olaniran O, Ajao O, Ojomu BK, Olawande O (2015). Safety of bread for human consumption in an urban community in Southwest Nigeria. African Journal of Food Science 9(5):272- 277.

AOAC (2005). Official method of Analysis (18th ed). Association of Officiating Analytical Chemists, Washington DC.

Bryan FL, Michanie SC, Alvarez P, Paniagna A (1988). Critical control point of street vended foods in the Dominican Republic. Journal of Food Protection 51(5):373-383. https://doi.org/10.4315/0362-028X-51.5.373

Fawole MO, Oso BA (2004). Characterization of bacteria. Laboratory manual of microbiology. $4^{\text {th }}$ edition, Spectrum book Ltd, Ibadan, pp 24- 33.

FEHD (2002). Food and Environmental Hygiene Department. Microbiological guide for ready-to-eat food. Risk assessment section, food and environmental hygiene department 43/F, Queensway, Hong Kong pp 3-4.

Feltes MMC, Arisseto-Bragotto AP, Block JM (2017). Food quality, food-borne diseases, and food safety in the Brazilian food industry. Food Quality and Safety Review 1:13-27.

ICMSF (1998). International Commission on Microbiological Specification of Foods. Microorganisms in Food. Microbiological Testing in Food Safety Management. Academic publishers New York, pp 70-80.

Isong NB, Akpan MM, Udota HI, Barber L (2013). Antimicrobial and microbial assessment of bread in Abak LGA, Nigeria, West Africa. Journal of Microbiology and Biotechnology 3(3):155-159.

Lateef A, Davies TA, Adelekan A, Adelere IA, Adedeji AA, Fadahunsi AH (2010a). Akara Ogbomoso: microbiological examination and identification of hazards and critical control points. Food Science and Technology International 16:386-400. https://doi.org/10.1177/1082013210366894

Musaiger AO, Al-Jedah JH, D'Souza R (2007). Nutrition profile of bakery product consumed in Bahrain, Pakistan Journal of Nutrition 6:228-233. https://doi.org/10.3923/pjn.2007.228.233

Samson RA (1981). Identification: entonopathogenic Deuteromycetes. In: Burges HD (Ed). Microbial Control of Pest and Plant Diseases 1970-1980. Academic Press, London pp 106-109.

Sausa CP (2008). The impact of food manufacturing practices on food borne diseases. Brazilian Archives of Biology and Technology 51(4):615-623. https://doi.org/10.1590/S1516-89132008000400020

WHO (2002). Global Strategy for Food Safety. Geneva: WHO [13139241545747].

WHO (2007). Initiative to estimate the global burden of food born diseases. Geneva, pp 26- 28.
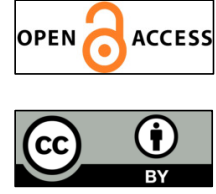

The journal offers free, immediate, and unrestricted access to peer-reviewed research and scholarly work. Users are allowed to read, download, copy, distribute, print, search, or link to the full texts of the articles, or use them for any other lawful purpose, without asking prior permission from the publisher or the author.

License - Articles published in Notulae Scientia Biologicae are Open-Access, distributed under the terms and conditions of the Creative Commons Attribution (CC BY 4.0) License.

(c) Articles by the authors; SHST, Cluj-Napoca, Romania. The journal allows the author(s) to hold the copyright/to retain publishing rights without restriction. 